\title{
Contamination Analysis of Escherichia coli on Broiler Chicken Meat in Traditional Markets of Medan City
}

\author{
J. Siregar, S. Umar, and N. D. Hanafi*
}

Animal Production Program Study, Faculty of Agriculture, Universitas Sumatra Utara, Padang Bulan, Medan 20155, Indonesia

*corresponding author : nevydiana@yahoo.co.id

\begin{abstract}
Escherichia coli (E. coli) is a gram-negative bacteria that can reduce meat quality and cause diarrhea if the amount is too much. This study investigates the presence of E. coli contamination in chicken meat sold in traditional markets in Medan. This research was conducted using the purposive sampling method and collected samples from $30 \%$ of each nine traditional markets with 32 samples. The traditional markets in Medan, namely Petisah, Central, Sei Kambing, Kampung Lalang, Kwala Bekala, Helvetia, Kampung Baru, Kemiri and Padang Bulan. Research was conducted by using the CFU / ml method with chromocult media. Samples were analyzed in the laboratory of the Regional Veterinary Disease Investigation Center Region 1 Medan. The results showed 32 samples of chicken meat had exceeded the maximum limit of microbial contamination. The highest total microbial average was in the Kampung Lalang market, 3.49 Log CFU / g, and the lowest was in the Kemiri market of 2.79 Log CFU / g. Based on the research results, it was found that the meat in the traditional markets of Medan was all contaminated with E. coli and had passed the maximum limit of bacterial contamination.
\end{abstract}

Keywords: chicken meat, contamination, e.coli, traditional markets, meat quality

Received [28 Juni 2021] | Revised [07 Juli 2021] | Accepted [19 Juli 2021]

\section{Introduction}

Humans need food from livestock as a source of protein. Animal protein is essential because it contains amino acids close to the amino acid required structure by humans to be easier to digest and more efficient in their use. However, food of animal origin will affect human health if it is unsafe; for example, it has a high population of microbes. Therefore, food safety from livestock is an absolute requirement that must be met. Microbes easily damage the meat. Damage to meat is characterized by a change in odor and mucus, which usually occurs when the number of microbes becomes millions or hundreds of millions of cells or more per one $\mathrm{cm}$ of the surface area of the meat. The surface of freshly slaughtered meat usually contains about $10^{2}$ to $10^{4}$ specific bacteria. It is mainly composed of mesophilic bacteria originating from the digestive tract and the outer surface of the animal. [1]

The research was carried out in traditional markets and analyzed at the Laboratory for Disease Investigation, Regional Veterinary Center I Jl. Jend. Gatot Subroto-Medan. This research was conducted from November to January 2021. 


\section{Materials and Methods}

\subsection{Materials}

Materials in this study were meat broiler chickens taken at 08:00 am from the traditional market with 32 samples. The media for testing were solution Buffered Pepton Water (BPW), media Chromocult, alcohol, aqua dest, cotton, and tissue.

\subsection{Methods}

This research was conducted by taking samples of a heterogeneous and even population from each traditional market with categorized big size market, medium and small. $30 \%$ of all traders in each of the traditional markets were taken.

\subsection{Research Implementation}

\subsubsection{Making Method Media Solution}

a. Media Buffered Peptone Water (BPW)

BPW weighed as much as 25 grams and was put into the Erlenmeyer flask and dissolved (homogenized) with $1000 \mathrm{ml}$ of sterile distilled water, then heated to boiling on a hot plate, then sterilized using an autoclave at a temperature of $121^{\circ} \mathrm{C}$ for 15 minutes.

\section{b. Making MediaChromocult Agar (CA)}

34.5 grams of Chromocult, put it in Erlenmeyer, and dissolve (homogenize) with $1000 \mathrm{ml}$ of aqua dest. It was then heated on a hot plate until boiling then sterilized by autoclave at a temperature of $121^{\circ} \mathrm{C}$ for 15 minutes.

\subsection{Test Method}

Testing the complete analysis of E.coli contamination was carried out by weighing 25 gram of the sample aseptically and placing it in a sterile plastic bag, and adding $225 \mathrm{ml}$ of BPW solution, then stomacher for 2 minutes. Next, pour $9 \mathrm{ml}$ of BPW solution into a sterile test tube and then add $1 \mathrm{ml}$ of 101 dilutions suspension with a sterile pipette into a $9 \mathrm{ml}$ BPW solution to get 102 dilutions. Do 103 dilutions in the same way.

Then one $\mathrm{ml}$ of the suspension from each dilution is put into a sterile petri dish. Then pour the Chromocult media that has been cooled to a temperature of $45^{\circ} \mathrm{C}$ into each petri dish containing the suspension and move it carefully to spread the microbial cells evenly. After the agar was frozen, the plates were incubated upside down at $35^{\circ} \mathrm{C}$ for 24 hours. After incubation, the number of colonies that grew on Chromocult agar was calculated. Colony characteristics obtained from breeding on these media are purple or blue-violet colonies. The purple color is formed due to the binding of E. coli bacteria with $\beta$-galactosidase and $\beta$-glucuronidase enzymes. 


\subsection{Data Analysis}

The data obtained from a test were processed then analyzed with a descriptive approach according to SNI 2897: 2008. Descriptive analysis was used to reveal facts, circumstances, conditions at the time of the research.

\section{Results And Discussion}

\subsection{Total Amount of Contamination E. coli}

The results of research on E. coli contamination in chicken meat are preasented on "Table 1".

Table 1. Results of E. Coli contamination in chicken meat at big size traditional markets

\begin{tabular}{|c|c|c|c|c|c|c|c|c|c|}
\hline \multirow{2}{*}{ Markets } & \multirow{2}{*}{ code } & \multicolumn{6}{|c|}{ Samples } & \multirow{2}{*}{ Total } & \multirow{2}{*}{ Average } \\
\hline & & P1 & P2 & P3 & P4 & P5 & P6 & & \\
\hline Petisah & & 3.47 & 3.47 & 3.47 & 3.73 & 3.41 & 3.30 & 20.85 & 3.47 \\
\hline Pusat Pasar & A2 & 3.39 & 3.47 & 3.56 & 3.47 & 3.47 & - & 17.36 & 3.47 \\
\hline Sei Kambing & A3 & 2.32 & 2.43 & 3.47 & 3.47 & 3.44 & - & 15.13 & 3.02 \\
\hline
\end{tabular}

"Table 1" shows that microbial contamination of E.coli was lowest in the Sei Kambing 3.02 CFU/g, Pusat Pasar3.47 CFU/and the highest is in the Petisah 3.47 CFU/g.

The research results on contamination E. coli in chicken meat at the research location in the markets with a medium-size market can be seen from "Table $2 "$.

Table 2. Test results E.coli on medium size traditional market.

\begin{tabular}{|c|c|c|c|c|c|c|c|}
\hline \multirow{2}{*}{ Markets } & \multirow{2}{*}{ Code } & \multicolumn{4}{|c|}{ Samples } & \multirow{2}{*}{ Total } & \multirow{2}{*}{ Average } \\
\hline & & P1 & P2 & P3 & P4 & & \\
\hline Helvetia & B1 & 3.23 & 3.25 & 3.47 & \multirow{3}{*}{3.30} & 9.95 & 3.31 \\
\hline Kampunglalang & B2 & 3.49 & 3.51 & 3.68 & & 13.98 & 3.49 \\
\hline Kwala Bkala & B3 & 3.39 & 3.47 & 3.47 & & 10.33 & 3.44 \\
\hline
\end{tabular}

"Table 2" shows that the medium ware found in the Helvetia market (B1) with of 3.31 Log CFU / $\mathrm{g}$ and the highest is in the Kampung Lalang market (B2) which was 3.49 Log CFU / g.

Table 3. Test results E. coli at small size traditional market

\begin{tabular}{|c|c|c|c|c|c|}
\hline \multirow{2}{*}{ Markets } & \multirow{2}{*}{ Code } & \multicolumn{2}{|c|}{ Samples } & \multirow{2}{*}{ Total } & \multirow{2}{*}{ Average } \\
\hline & & $\mathrm{P} 1$ & $\mathrm{P} 2$ & & \\
\hline Kemiri & $\mathrm{C} 1$ & 2.11 & 3.47 & 5.58 & 2.79 \\
\hline Padang Bulan & $\mathrm{C} 2$ & 3.32 & 2.44 & 5.76 & 2.88 \\
\hline Kampung Baru & $\mathrm{C} 3$ & 3.47 & 3.30 & 6.77 & 3.38 \\
\hline
\end{tabular}

"Table 3" shows the average contamination of E.coli. The highest was found in the Kampung Baru market (C3) with an average value of $3.38 \mathrm{Log} \mathrm{CFU} / \mathrm{g}$. 


\subsection{Factors Affecting Bacterial Contamination E. Coli}

\subsubsection{Cutting process and cutting tools}

The high rate of E. coli contamination is influenced by the process of slaughtering chickens and poor handlings after cutting, such as scattered chicken feathers and stagnant washing water due to piles of garbage. Following the statement [3], which states that the primary source of microbes found in carcass or meat is the process of slaughtering the animal itself, other sources of pollution are the outer surface of the body (skin, hair, and nails): the respiratory tract and the gastrointestinal tract.

In this study, the procedures for slaughtering chicken in traditional markets are in accordance with the halal standards issued by LPPOM MUI (2011). There are no different slaughtering procedures; all are the same in traditional markets; before being slaughtered, the chickens are rested so that the chickens are not stressed so that in the expenditure process.

When slaughtering is facing the Qibla, all workers are slaughtering by cutting the esophagus, trachea, jugular vein, and carotid artery (gastrointestinal tract and blood vessels). The chickens are waited for until they are completely dead. The blood is then removed from the body of the chicken. In this process, the chicken is not hung upside down. The chickens that have been slaughtered are placed in plastic bags or baskets so that the chickens do not jump out and wait for 2-3 minutes until the chickens do not move again.

The process of removing blood is not perfect because the chickens are not hanged so that the blood does not come out entirely and can have the potential as a growth medium for microorganisms. The meat is quickly damaged because the chicken is not hanged by blood and the chicken excreta that comes out at the time of slaughtering contaminates the feathers and skin of the chicken.

Bacterial contamination can also come from the tools used in the cutting process. Lack of sanitation on the cutting tool will cause a lot of bacteria to appear. According to [4], the factors that cause the high number of E. coli in chicken meat samples are the lack of cleanliness of the tools used at the time of cutting the meat. This will increase bacterial contamination in the meat and the placement of meat sold in the market at room temperature will accelerate growth. E. coli as a mesophilic microorganism will grow optimally at a temperature of $20-40^{\circ} \mathrm{C}$.

The source of water used for slaughtering livestock is very likely to be contaminated because the slaughtering process, especially skinning and removing the offal, is the most vulnerable point to contamination from the outside of the skin and contents of the digestive tract [5]. Washing conditions also need to be considered by using clean water and free from chlorine so that bacteria cannot enter during the cutting process. 


\subsection{The conditions around the place of cutting}

The environmental conditions in the big market were still far from the clean category. In contrast, in the market with medium and small size, the environmental conditions are good enough. There is no scattered garbage, the floor conditions in large and medium markets tend to be muddy. In contrast, in small markets, the floor conditions are adequately dry, and the level of traders' awareness of hygiene in small markets is better; it affects the difference in the amount of bacterial contamination in the chicken meat.

The existence of E. coli is influenced by poor sanitation hygiene, irregular sales places, poor hygiene of sales stalls, and lots of standing water and garbage scattered to be the primary source of microbes. In large and medium markets, the condition of the meat being sold is stacked and irregular. The meat that is placed on the sales table close to the offal can contaminate the carcass quickly [6].E. coli usually lives in the intestinal tracts of warm-blooded animals and can contaminate food in several ways, including contamination by hand, during evisceration, indirect contamination through water pollution, and during product packaging.

Another contamination occurs through the cleanliness of the seller's hands; dirty or contaminated hands can transfer bacteria. Hand washing is still a light activity that is still often forgotten in small markets where handwashing is available at the market entrance so that consumers can clean their hands before touching meat. According to [7], hand washing is quite effective in preventing contamination of food ingredients, for example, chicken carcass. This is related to the personal hygiene of people who process food ingredients.

\subsection{The condition of the seller mat and the cutting time}

Judging from the place where chicken meat is placed in traditional markets, it can also affect the level of bacterial contamination in the meat. The high level of pollution is influenced by the place of sale that uses a base that is difficult to clean so that it is easily contaminated from the sales mat. Stalls for good sales should use a porcelain table with a slope so that the table is easy to clean and water is easy to flow so that other bacteria do not contaminate the meat on the meat [8].

Based on the research results, the high amount of bacterial contamination is influenced by the time of slaughtering. In large markets slaughtering chickens is usually conducted very early in the morning than in small markets. Bacteria with contaminated meat in the market can grow, develop and carry out cell division while the meat is displayed. The influence of the time factor can be related to the number of bacteria. The time interval it takes for cells to divide is known as generation time. Bacterial single cells produce by binary fission, and their number increases geometrically. If the initial bacterial contamination is below the maximum microbial contamination limit, the number will increase after being displayed for some time so that it passes the maximum contamination limit [9]. 
Another factor that also affects E.coli contamination in chicken meat can be due to the poor condition of the rearing chicken in the rearing cage, where the cage is rarely cleaned of chicken manure and the state of the cage close to the disposal of the chicken manure. Feces are scattered, and the base of the cage that is rarely replaced causes bacteria in the feces to stick to the feathers and skin of the chicken. Therefore it is necessary to change the cage lining regularly and on a scheduled basis to make it cleaner and reduce bacterial contamination.

\section{Conclusion}

The analysis of E. coli on chicken meat in traditional markets in Medan city which were carried out in nine markets all exceeded the threshold set by SNI 1x101 CFU / g. E.coli contamination in chicken meat was mainly found in big markets, namely Petisah (3.47), Pusat pasar (3.47), and Kampung Lalang market (3.49).

\section{REFERENCES}

[1] Badan Standar Nasional. SNI 01-3924-2009 tentang mutu Karkas dan Daging Ayam Pedaging. Dapartemen Pertanian, Jakarta. 2009

[2] Jawetz, Ernest. J.L. Melnick dan E.A.Adelbeng. Mikrobiologi untuk Profesi Kesehatan. Edisi 16, Edisi 16, EGC, Penerbit Buku Kedokteran, Jakarta.1996

[3] Fernandes. Microbiology Handbook Meat Product. Surrey Leatherhead Food International. 2009

[4] Soeparno. Ilmu dan Teknologi Daging. Cetakan ke-5. Gajah Mada University Press.Yogyakarta. 2005

[5] Buckle KA, R.A.Edward, G.H. Fleed Ilmu Pangan.(diterjemahkan oleh Purnomo). Jakarta: Universitas Indonesia Press. 1987

[6] Forsythe.Microbiology of Safe Food. London : Blackweell Science. 2000

[7] Purnawijayanti. Penelitian Penanganan Pada Daging. Universitas Negeri Malang, Malang. 2001

[8] Direktorat Kesehatan Masyarakat Veteriner. Pedoman Teknis Program Penataan Kios Daging Unggas Di Pasar Tradisional. Direktorat Jendral Peternakan Dapertemen Pertanian. Jakarta

[9] Hardjopranjoto. Ilmu Kemajiran pada Ternak. Airlangga University Press, Hal 103-114. 1995

[10] Tatipikalawan, J. M. Studi Penetapan Harga ayam Kisar pada Tingkat Peternak di Pulau Kisar Kabupaten Maluku Tenggara Barat. Tesis PS. Ilmu Peternakan UGM Yogyakarta. 2006

[11] Ditjenak Direktorat Jenderal Peternakan. Statistik peternakan. Ditjenak Kementrian Pertanian Republik Indonesia Jakarta: DITJENAK. 2012 
[12] Juwita, U., Y Haryani, C Jose. Jumlah Bakteri Coliformdan Deteksiescherichiacolipada Daging Ayam Di Pekanbaru. JOM FMIPA Volume 1 No. 2 Juni. 2014 